Prepared in cooperation with the U.S. Environmental Protection Agency, Region 1 and the New Hampshire Department of Environmental Services

\title{
Bedrock Geology and Outcrop Fracture Trends in the Vicinity of the Savage Municipal Well Superfund Site, Milford, New Hampshire
}

Open-File Report 2013-1224 
THIS PAGE LEFT INTENTIONALLY BLANK 
Prepared in cooperation with the U.S. Environmental Protection Agency, Region 1 and the New Hampshire Department of Environmental Services

\section{Bedrock Geology and Outcrop Fracture Trends in the Vicinity of the Savage Municipal Well Superfund Site, Milford, New Hampshire}

By William C. Burton and Philip T. Harte

Open-File Report 2013-1224 


\title{
U.S. Department of the Interior SALLY JEWELL, Secretary
}

\section{U.S. Geological Survey Suzette M. Kimball, Acting Director}

\author{
U.S. Geological Survey, Reston, Virginia: 2013
}

For more information on the USGS - the Federal source for science about the Earth, its natural and living resources, natural hazards, and the environment, visit http://www.usgs.gov or call 1-888-ASK-USGS.

For an overview of USGS information products, including maps, imagery, and publications, visit http://www.usgs.gov/pubprod

To order this and other USGS information products, visit http://store.usgs.gov

Any use of trade, firm, or product names is for descriptive purposes only and does not imply endorsement by the U.S. Government.

Although this information product, for the most part, is in the public domain, it also may contain copyrighted materials as noted in the text. Permission to reproduce copyrighted items must be secured from the copyright owner.

Suggested citation:

Burton, W.C., and Harte, P.T., 2013, Bedrock geology and outcrop fracture trends in the vicinity of the Savage Municipal Well Superfund site, Milford, New Hampshire: U.S. Geological Survey Open-File Report 2013-1224, 17 p., http://pub.usgs.gov/of/2013/1224. 


\section{Contents}

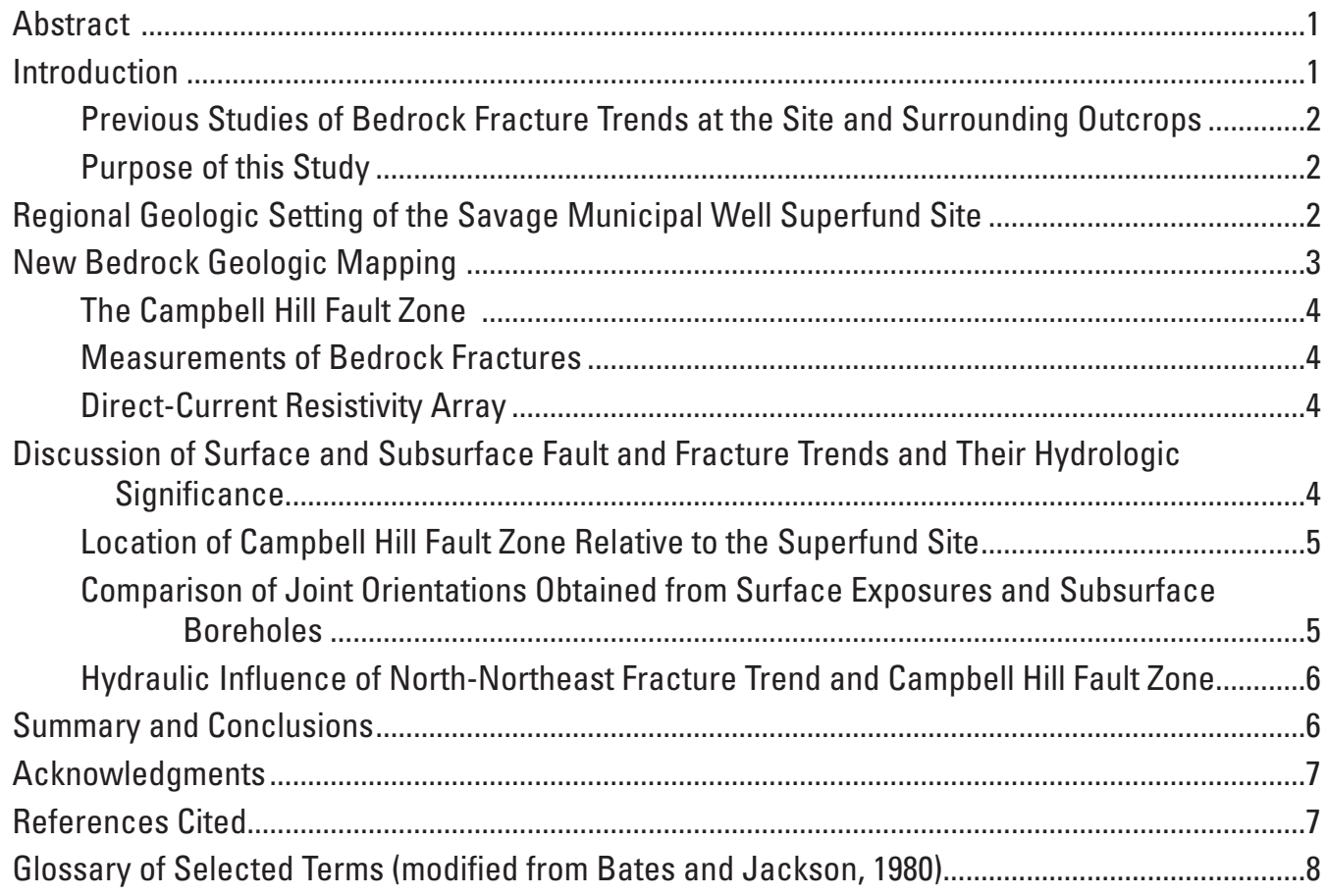

\section{Figures}

1. Map of the contamination area showing locations of bedrock monitoring wells, cone of depression from 2010 pump test in bedrock wells, tetrachloroethylene concentrations in bedrock in 2012, residential lots with bedrock wells, approximate sites of resistivity surveys, and trace of Campbell Hill fault zone

2. Reconnaissance bedrock geologic map of the northwestern part of the Milford, N.H., 7.5-minute quadrangle

3. Photograph showing body of vein quartz along the Campbell Hill fault zone south of the Souhegan River.

4. Photographs showing brittle structures in an outcrop of Spaulding Tonalite along the Campbell Hill fault about 0.5 kilometer south of the body of vein quartz shown in figure 3

5. Photographs showing brittle features north of the Souhegan River ..............................13

6. Stereonets and rose diagrams showing measured joint orientations in natural outcrops and man-made roadcuts within 3 kilometers of Savage Municipal Well Superfund site.

7. Polar plots showing results from azimuthal array direct-current resistivity

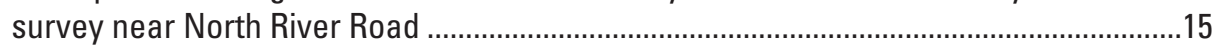

8. Features in optical televiewer logs of bedrock borehole BR-7 .........................................16

9. Summary orientation diagrams of planar features in bedrock boreholes .........................17 
THIS PAGE LEFT INTENTIONALLY BLANK 


\title{
Bedrock Geology and Outcrop Fracture Trends in the Vicinity of the Savage Municipal Well Superfund Site, Milford, New Hampshire
}

\author{
By William C. Burton and Philip T. Harte
}

\begin{abstract}
The Savage Municipal Well Superfund site consists of an eastward-directed plume of volatile organic compounds, principally tetrachloroethylene (PCE), in alluvium and glacial sand and gravel in the Souhegan River valley, just south of the river and about 4 kilometers west of the town of Milford, N.H. Sampling of monitoring wells at the site has helped delineate the extent of the plume and has determined that some contaminant has migrated into the underlying crystalline bedrock, including bedrock north of the river within 200 meters of a nearby residential development that was constructed in 1999. Borehole geophysical logging has identified a northeast preferential trend for bedrock fractures, which may provide a pathway for the migration of contaminant under and north of the Souhegan River. The current study investigates the bedrock geologic setting for the site, including its position relative to known regional geologic structures, and compiles new strike and dip measurements of joints in exposed bedrock to determine if there are dominant trends in orientation similar to what was found in the boreholes. The site is located on the northwestern limb of a northeast-trending regional anticlinorium that is southeast of the Campbell Hill fault zone. The Campbell Hill fault zone defines the contact between granite and gneiss of the anticlinorium and granite and schist to the northwest and is locally marked by lenses of massive vein quartz, minor faults, and fracture zones that could potentially affect plume migration. The fault zone was apparently not intercepted by any of the boreholes that were drilled to delineate the contaminant plume and therefore passes to the north of the northernmost borehole in the vicinity of the new residential area. Joints measured in surface exposures indicate a strong preferred direction of strike to the north-northeast corroborating the borehole data and previous outcrop and geophysical studies. The north-northeast preferred direction matches the direction of elongation of the cone of depression formed during a pump test of the bedrock wells and could explain a potential pathway for the migration of contaminant north of the river.
\end{abstract}

\section{Introduction}

A water supply well serving the town of Milford, N.H. (Savage Municipal Well, fig. 1), was discovered in 1983 to have unacceptable levels of volatile organic compounds (VOCs), principally tetrachloroethylene (PCE) (HMM Associates, Inc., 1989, 1991). The contaminant formed an east-trending plume, roughly 1.75 kilometers $(\mathrm{km})$ long and $1 \mathrm{~km}$ wide, in unconsolidated sand and gravel of the Souhegan River valley, upstream and west of the Milford town center (inset, fig. 1). The source was determined to be a cluster of small abandoned industrial sites about $4 \mathrm{~km}$ west of the town center and just south of the river (HMM Associates, Inc., 1989, 1991). The area of the plume was declared a Superfund site in 1991. A network of monitoring wells was installed, and pump-and-treat remediation began in the unconsolidated overburden. Monitoring and remediation activities continue today. Most wells that were drilled into the underlying fractured crystalline bedrock as part of the monitoring network were screened in the upper $50 \mathrm{ft}$ (15 m) of bedrock while a few others were deep bedrock wells (Harte, 2006; Weston, Inc., 2012; some shown in fig. 1). Therefore, little information was available from the deep bedrock prior to more recent (2010) work.

The remediation has succeeded in reducing levels of contaminant in the sand and gravel aquifer of the Souhegan River valley but has not been as effective in the underlying bedrock aquifer. In recent years, rising levels of PCE have been found in the shallow bedrock (Weston, Inc., 2012), suggesting that the bedrock is a reservoir for contaminants. An additional concern is the fact that a new (constructed in 1999) residential development was built north of the river. Each residence has a bedrock well, and the increased drawdown of the bedrock aquifer may render these wells susceptible to contamination from the plume. Accordingly, starting in 2010, the monitoring network was expanded with the installation of additional wells, some north of the river, to depths of several hundred feet into bedrock. To date, no contamination has reached the monitoring wells nearest the new development, although contamination has been documented north of the river (Weston, Inc., 2012) (fig. 1). Because of the very low primary porosity of the igneous and metamorphic bedrock, contaminants must travel by open fractures; therefore, determination of bedrock fracture orientations is important to predicting possible paths of plume migration. 


\section{Previous Studies of Bedrock Fracture Trends at the Site and Surrounding Outcrops}

A 1984 report by BCI Geonetics analyzed bedrock fractures and photolineaments near Milford as part of the initial assessment of the hazardous waste site. BCI Geonetics measured 114 joints in bedrock at 7 stations and determined two subequal population peaks in azimuth: 22 to 27 degrees and 108 to 116 degrees (BCI Geonetics, 1984). In addition, subhorizontal joints were observed at all outcrops with sufficient vertical relief. Spacing of these joints was 1 to 2 feet (ft) near the surface. With increasing depth, the average spacing increased. In nearby quarries, open joints were observed to depths of $25 \mathrm{ft}$ (BCI Geonetics, 1984).

In a geophysical study of the site, Lieblich and others (1992) used four surface-geophysical methods to determine the presence and orientation of subsurface fractures: ground-penetrating radar, inductive terrain conductivity, direct-current resistivity, and seismic refraction. The latter three techniques produced data that could be interpreted in terms of bedrock fracture orientations and yielded northeastern, and to a lesser extent, northwestern trends. For direct-current resistivity, anisotropy in bedrock was most apparent at longer electrode spacings and produced north-northeast-trending peaks in apparent resistivity that may indicate dominant fracture sets in the underlying bedrock.

A more recent bedrock study at the contaminated site (Weston, Inc., 2012) included drilling and multi-tool borehole geophysical logging of a number of new bedrock boreholes to depths of as much as $495 \mathrm{ft}$ below the bedrock surface (fig. 1). North-oriented, acoustic televiewer (ATV) and optical televiewer (OTV) logs yielded attitudes for every planar feature visible in the boreholes; OTV logs also recorded full-color images of bedrock with millimeter-scale resolution. The logs generally show a dominant north-northeastern trend in strike for fractures and other planar features, including foliation, with most planar features dipping moderately to steeply to the northwest (Weston, Inc., 2012).

\section{Purpose of this Study}

The purpose of this study is to identify spatial patterns of bedrock fractures and structural features in the vicinity of the Savage Municipal Well Superfund site. The data will be used in the ongoing development of conceptual and numerical models for contaminant transport and will help determine vulnerability of domestic bedrock wells in new residential areas north of the Souhegan River. The scope of activities includes the collection of bedrock structure and lithology data from naturally occurring outcrops and roadcuts in the area surrounding the Savage Municipal Well Superfund site, for purposes of comparison with previous outcrop data and the borehole and other geophysical data collected at the Superfund site. An azimuthal array direct-current resistivity survey was done to help identify fracture trends. All fieldwork was done within the northwestern part of the Milford, N.H., 7.5-minute quadrangle (fig. 2), within a 3-km radius of the site, and included classification of rock types by formation (map unit) and measurements of foliation, faults, and prominent joints and joint sets. Corroboration of the new data with the previous datasets mentioned above would strengthen any conclusions made about a dominant bedrock fracture trend and its possible role in contaminant transport. Also important to this study is the more accurate location of a prominent northeast-trending, steeply dipping fault, the Campbell Hill fault zone, which had previously been mapped in the region. The Campbell Hill fault zone may be a factor in contaminant transport near the new residential development.

\section{Regional Geologic Setting of the Savage Municipal Well Superfund Site}

The study site is directly underlain by alluvium and glacially derived sand and gravel of the Souhegan River valley that in turn overlie thin, discontinuous glacial till mantling bedrock (Harte, 2010). The highly permeable sand and gravel ranges in thickness from 50 to $130 \mathrm{ft}$ and comprises the Milford-Souhegan glacial-drift aquifer (Harte, 2010; Harte and Mack, 1992; Weston, Inc., 2012). North and south of the valley, the landscape is dominated by abundant glacial deposits, including both till and glacial outwash, with relatively sparse bedrock outcrops (Koteff, 1970).

The bedrock geology of the region encompasses two plutonic or metaplutonic units, the Spaulding Tonalite of Devonian age and the informally named Milford granite of Permian age; a highly deformed Silurian metasedimentary unit named the Rangeley Formation; and a deformed, partially melted assemblage of layered metamorphic and igneous rocks (migmatite), known as the Massabesic Gneiss Complex (MGC), of Neoproterozoic to Permian age (Lyons and others, 1997; Dorais and others, 2012). The Spaulding Tonalite and the Rangeley Formation are widespread in south-central New Hampshire, and the MGC forms a belt about $10 \mathrm{~km}$ wide that extends about $45 \mathrm{~km}$ northeast of the study area. The Milford granite crops out within the Milford 7.5-minute quadrangle in the Damon Pond pluton (Dorais and others, 2012). Correlative granite occurs in quadrangles to the east and south in the Hollis pluton (Lyons and others, 1997). The Milford granite and the MGC occur southeast of the Spaulding Tonalite and the Rangeley Formation and are separated from them by the Campbell Hill fault zone, a 
northeast-trending, down-to-the-northwest normal fault according to Lyons and others (1997). The Campbell Hill fault zone cuts through most of southeastern New Hampshire and passes within $1 \mathrm{~km}$ of the Superfund site (Lyons and others, 1997).

Aleinikoff mapped the Milford 15-minute quadrangle as part of his Ph.D. thesis, which includes the study area, and dated the Milford granite at about $275 \mathrm{Ma}$ (Permian) (Aleinikoff, 1978; Aleinikoff and others, 1979). Studies of the age and tectonic provenance of the MGC and its regional metamorphic history have been conducted by Dorais and others $(2001,2012)$ and have determined that the protolith of the MGC is Neoproterozoic in age (Dorais and others, 2012).

The most recent detailed bedrock mapping in the region prior to this study is a bedrock geologic map of the Pinardville 7.5-minute quadrangle (Burton and Armstrong, 2013), which adjoins the Milford 7.5-minute quadrangle to the northeast. In the Pinardville quadrangle, the MGC is a complexly deformed package of layered metasedimentary and granitic gneisses with ages ranging from Neoproterozoic to Permian. Structurally, the MGC is at the core of the northeast-trending Massabesic anticlinorium of Lyons and others (1997). Foliation on the northwestern limb of the anticlinorium generally dips to the northwest, and foliation on its southeastern limb dips to the southeast. Northwest of the MGC, the Rangeley Formation consists of several tightly folded metasedimentary schist units that are intruded by Spaulding Tonalite, which is also deformed.

The Campbell Hill fault zone is mapped in the Pinardville quadrangle as a northeast-trending zone about $2 \mathrm{~km}$ wide within the belt of Rangeley Formation and Spaulding Tonalite, on the northwestern limb of the Massabesic anticlinorium. The fault zone is characterized by northeast-trending brittle faults, 1 to $3 \mathrm{~km}$ in length, that contain abundant quartz-hematite mineralization and local breccia and gouge. Abundant slickensided surfaces along these faults indicate both down-to-the-northwest and left-lateral, strike-slip movement. The fault zone also contains distinctive lenses of vein quartz that are elongate in a northeastern direction and are up to $2 \mathrm{~km}$ long. The quartz lenses contain complex internal textures indicating multiple events of brecciation and injection. The contact of the Rangeley and Spaulding rocks with the MGC is marked by a ductile fault, the Powder Hill fault, that also exhibits a down-to-the-northwest and left-lateral, strike-slip sense of motion but under higher temperatures and pressures; this fault was intruded by Permian granite following ductile fault movement (Burton and Armstrong, 2013). Folding, metamorphism, and intrusion of the Rangeley Formation rocks by Spaulding Tonalite occurred in the middle Paleozoic Acadian orogeny. Metamorphism and partial melting, ductile faulting, and antiformal uplift of the MGC culminated in the late Paleozoic Alleghanian orogeny to produce the Massabesic anticlinorium (Dorais and others, 2012). The brittle faulting and emplacement of quartz lenses in the Campbell Hill fault zone are likely younger (Mesozoic) in age; muscovite in one of the lenses has been dated as early Triassic (Dorais and others, 2012).

\section{New Bedrock Geologic Mapping}

The new geologic map (fig. 2) shows major lithologic contacts, foliations, outcrop-scale minor faults, and the location of the Campbell Hill fault zone. Joints are omitted for clarity. Schist of the Rangeley Formation (Srs, fig. 2) is a gray to rusty, medium- to fine-grained, biotite-muscovite schist with well-developed foliation. The Spaulding Tonalite (Dst, fig. 2) is a lightgray, medium- to coarse-grained biotite granitoid with lesser amounts of muscovite that is typically massive to weakly foliated. It commonly contains white to pink, coarse-grained pegmatitic segregations and locally darker, wispy, mica-rich schlieren that probably represent partially assimilated inclusions of Rangeley schist. Locally occurring in this belt are unmapped migmatitic zones containing alternating meter-scale layers of schist and granite. A larger, map-scale inclusion of Rangeley schist within Spaulding Tonalite is shown as a separate body of Srs (fig. 2).

The Milford granite (Pmg, fig. 2), southeast of the Campbell Hill fault zone, is a light-gray to pink, medium-fine- to medium-grained, massive to weakly foliated biotite granite with minor muscovite. Like the Spaulding Tonalite, it contains pegmatitic segregations and inclusions of the country rock (PZmg, fig. 2) that it intruded. The Massabesic Gneiss Complex (PZmg) is a dark-gray, medium-fine- to fine-grained potassium feldspar-plagioclase-biotite-quartz gneiss that is so heavily intruded by the Milford granite that only one mappable body occurs in the study area (fig. 2).

The schist and gneiss of the Rangeley Formation and the Massabesic Gneiss Complex were subjected to high-grade (upper amphibolite) metamorphic conditions in the middle and late Paleozoic, respectively (Dorais and others, 2012). Metamorphic foliation in the Rangeley is expressed by aligned micas (biotite and muscovite), whereas in the Massabesic, foliation is typically expressed by alternating, centimeter-scale mafic (biotite- and (or) hornblende-rich) and felsic (quartz and plagioclase feldspar) layering. Foliation in both the Spaulding Tonalite and Milford granite is inconspicuous or absent; where present, it is expressed by aligned biotite and lesser muscovite. Both granites were intruded during regional tectonic events, and their foliation orientations are undoubtedly influenced by deformation to some degree. Foliation attitudes in the map area are mostly northeast-trending and northwest-dipping (fig. 2); this trend reflects their position on the northwestern limb of the Massabesic anticlinorium, whose northeast-trending axial trace passes to the southeast of the area shown in figure 2. 


\section{The Campbell Hill Fault Zone}

In the study area, the Campbell Hill fault zone (CHFZ, fig. 2) is mapped as a narrow fault contact between Milford granite to the southeast and Spaulding Tonalite to the northwest. The fault zone is marked by map-scale bodies of vein quartz, which define the trace of the fault contact for about $1 \mathrm{~km}$ south of the Souhegan River. The bodies of vein quartz (q, fig. 2) are white to reddish weathering, have a massive, relatively unfractured appearance, and contain multiple sets of crosscutting, centimeterscale quartz veins that suggest multiple generations of dilation and vein injection accompanying normal faulting (fig. 3).

The fault zone is also marked by a subvertical fracture zone (fig. 4A) and adjacent minor, west-dipping fault surfaces with downdip slickenlines (fig. 4B) in an outcrop just south of the largest quartz bodies (q, fig. 2). Movement sense could not be determined for the minor faults, but their attitudes and the downdip plunges of the slickenlines are consistent with northwestside-down normal fault motion found on the Campbell Hill fault zone in the Pinardville quadrangle (Burton and Armstrong, 2013). Two other slickensided fault surfaces were mapped within $3 \mathrm{~km}$ of the Campbell Hill fault zone: one in the Milford granite (figs. 2, 5A) and the other in the Spaulding Tonalite (fig. 2). The slickenlines on both faults plunge at moderate angles, indicating a strike-slip component to movement. North of the Souhegan River, the Campbell Hill fault zone is projected through an area of little exposure between a roadcut in Milford granite on North River Road (figs. 2, 5A) and a pavement outcrop of Spaulding Tonalite in an abandoned gravel pit, near an extensive exposure of Rangeley schist at Purgatory Falls (figs. 2, 5B).

\section{Measurements of Bedrock Fractures}

Two hundred and fifty-five joints were measured, including multiple subparallel joints in joint sets such as those shown in figure $5 \mathrm{~B}$. For each joint set, one representative measurement was taken and the number of joints counted. Orientations of the joints are shown in figure 6 as both stereonets and rose diagrams: the top row shows orientations for all joints measured in the quadrangle, followed by joint data grouped by individual formation. The diagrams show a dominant steeply dipping joint set that strikes north-northeast, and a lesser set-also steeply dipping — that trends east-northeast. The total range of azimuths for the dominant joint orientation in the three formations with abundant joint data is 7.9 to 16.6 (total 112 joints). About two-thirds of the joints in the principal north-northeast trend have dips of 60 degrees or greater. A prominent secondary peak in the Rangeley Formation and the Spaulding Tonalite has azimuths of 84.2 and 87.3 degrees, respectively. The Milford granite has a greater diversity of secondary peaks, including three subequal peaks at 31.0, 79.6, and 112.7 degrees. Spacing in joint sets (not graphically shown) ranged from $5 \mathrm{~cm}$ to $3 \mathrm{~m}$ and was typically one to several decimeters. Joint apertures were not measured because of their likely enlargement by weathering, and a significant number of measurements were of joint faces in which the opposing block had been removed. Foliation exerted virtually no influence on joint orientation, and no foliation-parallel fractures were measured.

\section{Direct-Current Resistivity Array}

An azimuthal array direct-current resistivity survey was conducted to identify trends in bedrock anisotropy near the farm field west of North River Road and north of Route 101 and the Souhegan River (fig. 1). The array had half-current electrode spacings of 3 to $30 \mathrm{~m}$ and measured directional apparent resistivities at 30-degree angles. The direction of maximum apparent resistivity measured by the azimuthal array will be parallel to the fracture strike (Habberjam, 1972).

The maximum apparent resistivities were tabulated for each electrode spacing as an indicator of fracture strike. The 3-m half-current electrode spacing has a shallow depth to penetration and likely partially measures the resistivity of the unsaturated sections of the surficial unconsolidated sediments (fig. 7A). A maximum apparent resistivity of approximately 3,500 ohm-meters (ohm-m) was measured at 60 degrees. For the longest (30-m) half-current electrode spacing, which likely measures the shallow bedrock, a maximum apparent resistivity of approximately 2,200 ohm-m was measured at 330 degrees (fig. 7B). This indicates a northwesterly direction for the primary fracture orientation.

\section{Discussion of Surface and Subsurface Fault and Fracture Trends and Their Hydrologic Significance}

Several structural features were mapped that have important implications for groundwater flow and transport. These features include the location of the Campbell Hill fault zone and the pervasive nature of the dominant north-northeast-trending fracture sets. 


\section{Location of Campbell Hill Fault Zone Relative to the Superfund Site}

The location of the Campbell Hill fault zone is better constrained south of the Souhegan River, where it is marked by quartz bodies and faulted outcrops, than to the north, where it is mapped between two exposures about $1 \mathrm{~km}$ apart, as discussed above (fig. 2). In contrast to the 2-km-wide zone mapped in the Pinardville quadrangle (Burton and Armstrong, 2013), the Campbell Hill fault zone in the Milford quadrangle is shown as a single to locally splaying fault. The apparently narrower fault zone in the Milford quadrangle may be an artifact of the relative paucity of exposure compared to the Pinardville quadrangle, so that fewer fault-related features are exposed. It is unclear whether the two slickensided fault surfaces mapped about 1 to $3 \mathrm{~km}$ away from the mapped trace of the Campbell Hill fault zone, discussed above (fig. 2), are actually part of the fault zone, since they lack the hematite mineralization of the faults that mark the broad fault zone in the Pinardville quadrangle to the northeast.

Additional bedrock information was obtained from the wells logged as part of the site investigation (Weston, Inc., 2012). In a few boreholes, particularly BR-7 north of the river (fig. 1), zones of country rock within granite gneiss are dark and fine grained, consistent with the biotite-rich Massabesic Gneiss Complex (fig. 8A); the orientation of the gneissic foliation in BR-7 is shown in figure 2. None of the boreholes intersected quartz bodies, major fracture zones, or hematite mineralization indicative of the fault zone elsewhere, although BR-7 has several east- to southeast-dipping minor faults with visible offset (fig. 8B) (Weston, Inc., 2012). Therefore, the borehole data are consistent with the site being within the Massabesic anticlinorium and southwest of the Campbell Hill fault zone (figs. 1 and 2). Northeast of the Pinardville quadrangle, Kerwin (2003) mapped the Campbell Hill fault zone as a single fault within a silicified zone less than $0.5 \mathrm{~km}$ wide, supporting the idea that this fault zone can be quite narrow in places along its length.

Well records from the residential development north of the Souhegan River were examined to identify geologic or hydrologic data that would provide insight into the distribution of rock types and the presence of major structural features, such as the Campbell Hill fault zone. Over 60 well records were reviewed from wells that were located near the fault zone. Most records contained minimal information on rock type or other information that could elucidate significant lithologic changes or structural features. However, yields of several wells near the projection of the fault were very low ( $<1$ gallon per minute (gpm)) and required hydrofracturing techniques to boost yields to usable levels. One explanation for this might be that the wells intercepted one or more silicified zones along the fault zone similar to the body of vein quartz mapped south of the river and that the silicified rock acted as a low-permeability barrier, which produced very low yields.

\section{Comparison of Joint Orientations Obtained from Surface Exposures and Subsurface Boreholes}

The 1984 report by BCI Geonetics measured 114 joints at 7 locations and documented a peak in joint azimuth of about 22 to 27 degrees, representing about 37 percent of the data, and a slightly lesser peak of about 108 to 116 degrees, in about 32 percent of the data. In comparison, for this report 255 joints at 40 locations were measured, including three of the BCI locations, resulting in a peak azimuth at about 13 degrees that represents about 60 percent of the data and a lesser peak at about 88 degrees representing about 30 percent of the data (fig. 6, top right). Excluding joints measured in the Milford granite (fig. 6), no notable peak exists for the data measured during this study that corresponds to the secondary east-southeast trend found by BCI. The four BCI localities that were not revisited in this study are all to the east, in Milford granite and (or) Massabesic Gneiss Complex, farther away from the Campbell Hill fault zone than the outcrops studied in this report. One explanation for the slight difference in the Milford granite data may be that the north-northeastern joint trend is more dominant in the other rock types that are more prevalent nearer the fault zone, whereas the southeastern trend becomes more apparent farther from the fault zone where the Milford granite is prevalent. Thus, the comparison suggests that spatial variability exists in the fracture trend data in the region. In the Pinardville quadrangle, peaks in fracture orientation appear to be more diverse and less northeast-dominant away from the Campbell Hill fault (Burton and Armstrong, 2013).

Twelve boreholes at the site were logged using OTV (optical televiewer) and ATV (acoustic televiewer) instruments. Geophysical contractors attempted to measure every planar feature in bedrock that might be hydraulically significant (Weston, Inc., 2012). An examination of the fracture picks indicates that for the most part features were picked that were visible in both the OTV and ATV logs. Figure 9A shows lower-hemisphere equal-area stereonets of poles to fracture planes for selected boreholes in which the fractures are ranked by transmissive potential (Weston, Inc., 2012). Also shown are rose diagrams of dip direction, which is 90 degrees from strike, and statistical summaries. Figure $9 B$ is a single summary diagram by Northeast Geophysical of all planar features (including foliation) in all holes that it logged. Data collected by both geophysical contractors indicate that the dominant trend for fractures in the boreholes is north-northeast to northeast (Weston, Inc., 2012), similar to what was recorded in surface exposures in this study. Gently dipping to subhorizontal exfoliation fractures are present in all boreholes except MW-30 (fig. 9A). These fractures are not apparent in the outcrop data (fig. 6), which is likely due to sampling bias. The ages of the joints are generally considered Mesozoic or younger (for example, Manning and de Boer, 1989) and postdate Permian Alleghanian high-grade regional metamorphism. 
For the azimuthal array direct-current resistivity survey, the maximum apparent resistivities from the 30-m half-current electrode spacing are consistent with resistivities from the shallow bedrock that were measured at a similar electrode spacing (Lieblich and others, 1992) (fig. 1). Typically during directional resistivity surveys, the maximum apparent resistivity aligns with the primary fracture orientation, whereas the minimum resistivity is perpendicular to the primary fracture trend. A maximum resistivity from our data for the $30-\mathrm{m}$ half spacing at 150 and 330 degrees (fig. 7) suggests a northwest-striking fracture set is present. High resistivities were also measured in the northern ( 0 and 180 degrees) and northeastern ( 30 and 210 degrees) directions as well, indicating fractures trending in those directions. A predominant northwestern fracture trend in our data and a secondary north to northeastern fracture trend differs from the results of Lieblich and others (1992) that show maximum resistivities aligning in a northeastern direction with a secondary northwestern fracture set. The difference in directional trends could be due to differences in bedrock depth, which is about $30 \mathrm{ft}$ shallower near the site of the 1992 survey (fig. 1). In addition, the site of this study's resistivity survey is closer to the Campbell Hill fault zone (fig. 1) and may be detecting fracture features associated with the fault.

\section{Hydraulic Influence of North-Northeast Fracture Trend and Campbell Hill Fault Zone}

An aquifer test was conducted by withdrawing groundwater from a well producing from bedrock at the source of the plume and observing drawdown in adjacent bedrock wells (Weston, Inc., 2012). Results indicate that significant hydraulic connectivity exists between the pumping well (BR-6, fig. 1) and two wells to the north-northeast: MW-2R and BR-3, north and south of the river, respectively, and to a lesser extent with another well north of the river, MW-30 (fig. 1). The cone of depression produced by the pumping test shows a distinct elongation in a north-northeastern direction (fig. 1), similar to mapped fracture trends. The logical conclusion is that the dominantly north-northeast-striking, steeply dipping regional fracture trend that is observed both at the surface and in the subsurface is hydraulically significant and has the potential to transport contamination in a north-northeastern direction under the Souhegan River.

Less well understood is the effect the Campbell Hill fault zone has on groundwater flow paths and potential migration of the contaminant plume. As mapped north of the river (figs. 1 and 2), the fault zone trends about 40 degrees northeast and therefore is at an angle to the measured pump-test drawdowns and surface fractures (figs. 1 and 6, respectively), which trend about 10 to 20 degrees northeast, and most of the subsurface fractures (fig. 9); therefore a northward-migrating plume would likely intersect the CHFZ at an acute angle. Features in the fault zone, such as the relatively unfractured bodies of vein quartz, which are found south of the Souhegan River but whose existence north of the river is unknown due to poor exposure, would likely act as a subsurface barrier to movement. However, the brittle fracture zones and normal faults associated elsewhere with the fault zone, which suggests dilation, would be more conducive to fluid flow, perhaps with a preferred direction parallel to the fault zone.

\section{Summary and Conclusions}

The Savage Municipal Well Superfund site is located on the northwestern limb of a northeast-trending anticlinorium that is cored by the Massabesic Gneiss Complex and, locally, the informally named Milford granite that intrudes the complex. The site is southeast of the Campbell Hill fault zone, which defines the contact between the anticlinorium and the Spaulding Tonalite and Rangeley Formation to the northwest. The rocks were all subjected to high-grade (upper amphibolite facies) metamorphism and deformation in the middle and late Paleozoic, and uplift of the anticlinorium in the late Paleozoic has produced a predominantly northeast-striking and northwest-dipping regional foliation. Movement along the Campbell Hill fault zone continued into the Triassic after uplift and cooling, accompanied by injection of vein quartz and the formation of distinctive, large, lens-shaped quartz bodies, as well as development of normal faults and fractures along the fault zone. Joints in the bedrock away from the Campbell Hill fault zone also formed in the Triassic or later.

For this study, orientation of 255 joints in bedrock were measured at 40 natural outcrops and man-made roadcuts, and the results indicate a strong north-northeastern trend in strike, with most joints dipping greater than 60 degrees. This differs somewhat from an earlier study that found the north-northeastern trend but a nearly subequal east-southeastern trend; the difference may be partly explained by a greater concentration of measurements near the northeast-trending Campbell Hill fault zone in the current study. The new surface fracture measurements agree well with trends for bedrock fractures measured in 12 boreholes at the site using ATV and OTV logs, which also show a strong north-northeastern trend, with moderate to steep dips. The northnortheastern trend also parallels the elongation direction of the cone of depression formed during an aquifer test at the Superfund site that extends across the Souhegan River, suggesting that this fracture trend could potentially be a significant pathway for contaminants north of the river. A new direct-current resistivity survey north of the river suggests primarily northwest-trending fractures with a secondary north-to northeast-trending fracture set. This differs from a previous survey that found predominantly 
northeast-trending fractures; the difference may be partially explained by deeper bedrock and closer proximity to the Campbell Hill fault at the site of the new survey.

The exact location and nature of the Campbell Hill fault zone near the Superfund site is not well understood due to poor surface exposure. According to the well logs from the site, the fault zone was likely not penetrated by drilling and lies to the north and northwest of the northernmost monitoring well drilled for the contamination study. The fault zone could alternatively act both as a barrier, if large quartz bodies occur in the subsurface north of the site, or as a conduit, due to the hydraulically open nature of fracture zones and normal faults that mark the fault zone.

\section{Acknowledgments}

This study was conducted as part of the remedial effort at the Savage Municipal Well Superfund site, specifically Operable Unit 3 (OU3) and is a collaborative effort between Federal, State, and local governments, and private companies and individuals. The authors wish to thank Richard Hull, site remedial project manager for the U.S. Environmental Protection Agency (USEPA), Region 1; and Robin Mongeon, project manager for the New Hampshire Department of Environmental Services (NHDES) for their cooperation and support.

\section{References Cited}

Aleinikoff, J.N., 1978, Structure, petrology, and U-Th-Pb geochronology in the Milford 15-minute quadrangle, New Hampshire: Hanover, N.H., Dartmouth College, unpublished Ph.D. thesis, 247 p.

Aleinikoff, J.N., Zartman, R.E., and Lyons, J.B., 1979, U-Th-Pb geochronology of the Massabesic Gneiss and the granite near Milford, south-central New Hampshire; New evidence for Avalonian basement and Taconic and Alleghanian disturbances in eastern New England: Contributions to Mineralogy and Petrology, v. 71, p. 1-11.

Bates, R.L., and Jackson, J.A., ed., 1980, Glossary of geology (2d ed.): Alexandria Va., American Geological Institute, 751 p.

BCI Geonetics, 1984, Bedrock fracture fabric analyses of the Savage well, Grugnale pit and Milford landfill hazardous waste study areas: Hydrogeologic support investigation for NHWS and PCC, 14 p.

Burton, W.C., and Armstrong, T.R., 2013, Bedrock geologic and joint trend map of the Pinardville quadrangle, Hillsborough County, New Hampshire: U.S. Geological Survey Open-File Report 2013-1027, one sheet, scale 1:24,000.

Dorais, M.J., Wintsch, R.P., and Becker, H., 2001, The Massabesic Gneiss Complex, New Hampshire; A study of a portion of the Avalon Terrane: American Journal of Science, v. 301, p. 657-682.

Dorais, M.J., Wintsch, R.P., Kunk, M.J., Aleinikoff, J.N., Burton, W.C., Underdown, Christine, and Kerwin, C.M., 2012, P-T-t conditions, $\mathrm{Nd}$ and $\mathrm{Pb}$ isotopic compositions and detrital zircon geochronology of the Massabesic Gneiss Complex, New Hampshire; Isotopic and metamorphic evidence for the identification of Gander basement, central New England: American Journal of Science, v. 312, p. 1049-1097.

Habberjam, G.M., 1972, The effects of anisotropy on square array resistivity measurements: Geophysical Prospecting, v. 20, p. 249-266.

Harte, P.T., and Mack, T.J., 1992, Geohydrology of, and simulation of groundwater flow in the Milford-Souhegan glacial-drift aquifer, Milford, New Hampshire: U.S. Geological Survey Water-Resources Investigations Report 91-4177, 90 p.

Harte, P.T., 2006, Effects of a remedial system and its operation on volatile organic compound-contaminated ground water, Operable Unit 1, Savage Municipal Well Superfund site, Milford, New Hampshire, 1998-2004: U.S. Geological Survey Scientific Investigations Report 2006-5083, 80 p.

Harte, P.T., 2010, Hydrostratigraphic mapping of the Milford-Souhegan glacial-drift aquifer, and effects of hydrostratigraphy on transport of PCE, Operable Unit 1, Savage Superfund Site, Milford, New Hampshire: U.S. Geological Survey Open-File Report 2010-1047, 34 p., 3 pls. 
HMM Associates, Inc., 1989, Draft remedial investigation, Savage well site, Milford, New Hampshire: Concord, Mass., no. $2176 \mathrm{HAZ} / 2880,218 \mathrm{p}$.

HMM Associates, Inc., 1991, Remedial investigation, Savage well site, Milford, New Hampshire: Concord, Mass., no. 2176 HAZ/4814, $800 \mathrm{p}$.

Kerwin, C.M., 2003, Geology of the Candia 7.5 minute quadrangle and portions of the Northwood, Barrington and Mt. Pawtuckaway 7.5 minute quadrangles, southeastern New Hampshire: New Hampshire Geological Survey Publication Geo-153048000-BMOF [bedrock map open file], draft color map, scale 1:48,000.

Koteff, Carl, 1970, Surficial geologic map of the Milford quadrangle, Hillsborough County, New Hampshire: U.S. Geological Survey Geologic Quadrangle Map GQ-881, scale 1:62,500.

Lieblich, D.A., Haeni, F.P., and Lane, J.W., Jr., 1992, Integrated use of surface-geophysical methods to indicate subsurface fractures at Milford, New Hampshire: U.S. Geological Survey Water-Resources Investigations Report 92-4056, 37 p.

Lyons, J.B., Bothner, W.A., Moench, R.H., and Thompson, J.B., Jr., 1997, Bedrock geologic map of New Hampshire: Reston, Va., U.S. Geological Survey, scale 1:250,000.

Manning, A.H., and de Boer, J.Z., 1989, Deformation of Mesozoic dikes in New England: Geology, v. 17, no. 11, p. $1016-1019$.

Salvini, Francesco, 2012, The Structural Data Integrated System Analyser (version 4.85): Rome, Italy, Universita degli Studi di "Roma Tre,” Dipartimento di Scienze Geologiche, software available at http://host.uniroma3.it/progetti/fralab/Downloads/ Programs/.

Weston, Inc., 2012, Draft bedrock investigation technical memorandum, Savage Municipal Water Supply Superfund Site OU3, Milford, New Hampshire: Concord, N.H., Weston Solutions, Inc., 1270 p.

\section{Glossary of Selected Terms (modified from Bates and Jackson, 1980)}

Anticlinorium A map-scale, upward-arching composite structure containing smaller anticlines (upward-arching folds).

Exfoliation The process by which concentric shells or plates parallel to an exposed rock surface are spalled off.

Foliation A planar fabric consisting of textural or structural features in igneous and metamorphic rock, particularly from compositional layering and the planar arrangement of crystals.

Joint A planar fracture, crack, or parting in a rock, without shear displacement. Often occurs with parallel joints to form part of a joint set.

Orogeny The process by which mountains are formed.

Pegmatite An exceptionally coarse-grained igneous rock, with interlocking crystals, usually found as irregular dikes, lenses, or veins. Most grains are 1 centimeter or more in diameter. Generally light colored and granitic in composition.

Schlieren Tabular or lensoid concentrations of minerals within an intrusive igneous intrusion rock. Typically inclusions of country rock that are modified to a similar composition as the intrusive rock, but darker in color.

Slickenside A lineated fault surface containing grooves or aligned mineral growths that indicate the direction of slip on the fault. 


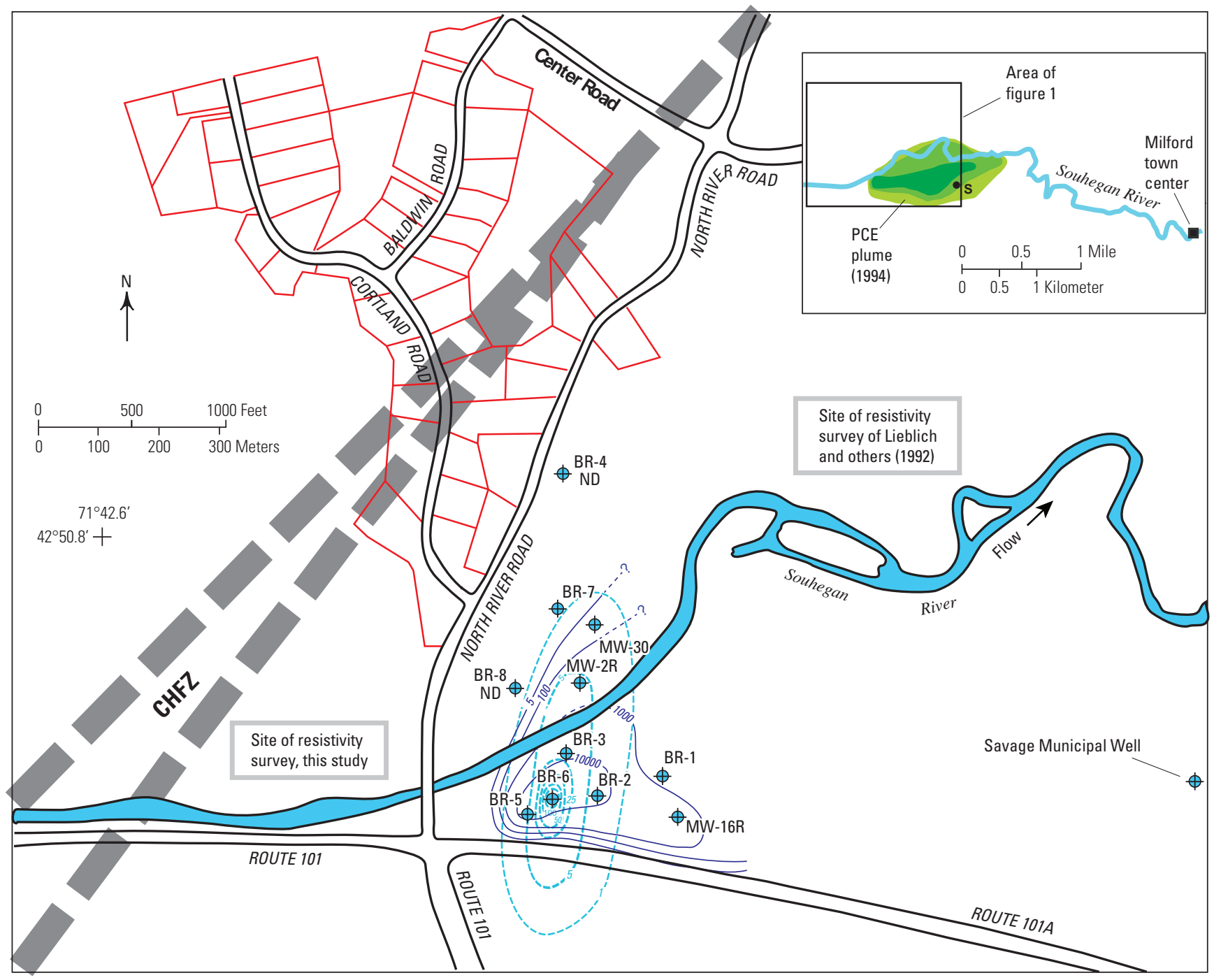

Figure 1. Map of the contamination area showing locations of bedrock monitoring wells (BR and MW numbers, some omitted for clarity), cone of depression from 2010 pump test in bedrock wells (dashed blue lines, drawdown of water table in feet), tetrachloroethylene (PCE) concentrations in bedrock in 2012 (purple lines, concentrations in micrograms per liter; modified from Weston, Inc., 2012), residential lots with bedrock wells (red polygons), approximate sites of resistivity surveys, and trace of Campbell Hill fault zone (CHFZ). Wells BR-4 and BR-8 had no detectable PCE (ND). Inset shows approximate 1994 extent of PCE plume in unconsolidated sediment west of Milford town center (darker shade of green = greater concentration). $\mathrm{S}=$ Savage Municipal Well. Plume extent in bedrock is much less well known. 


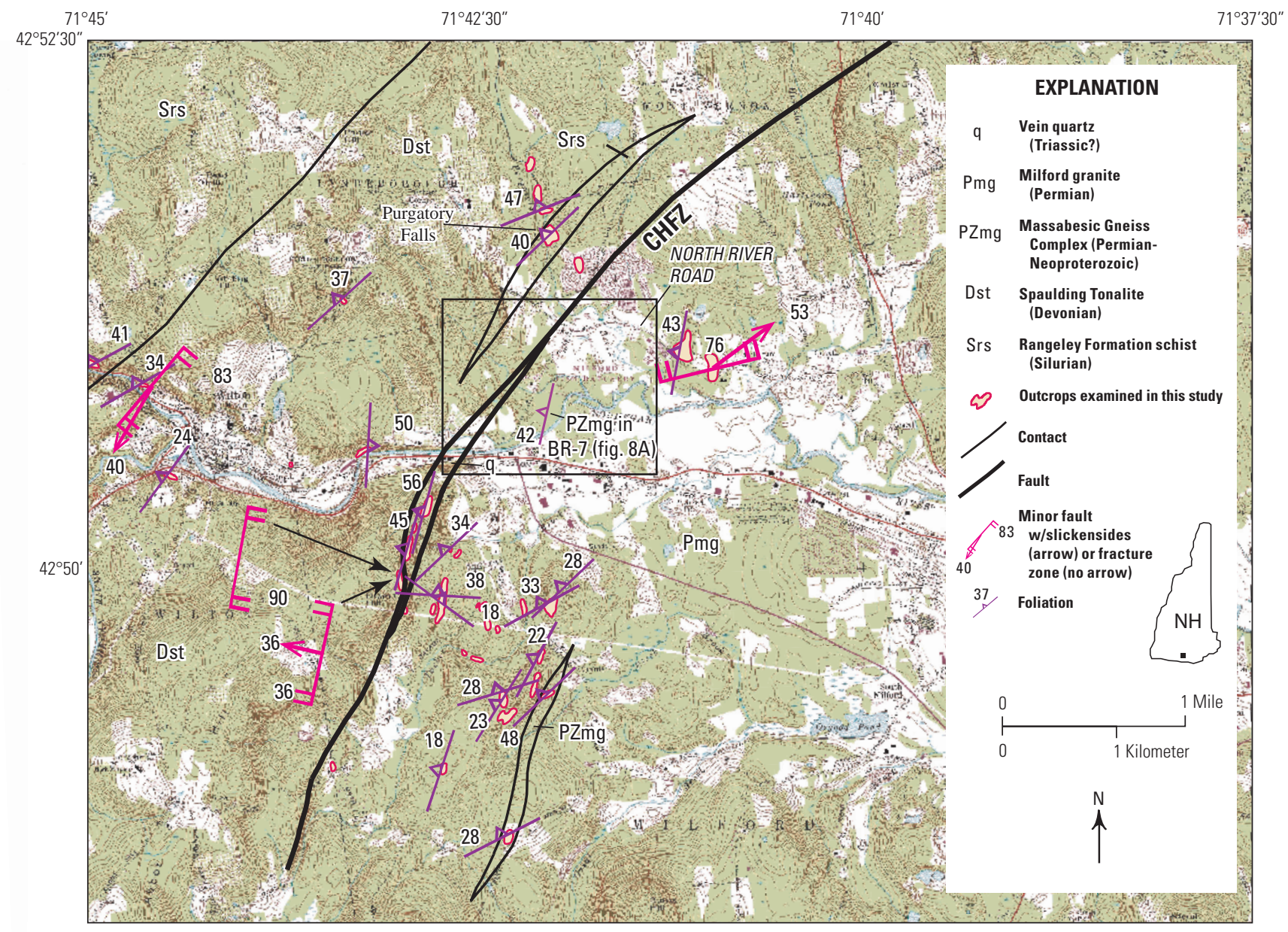

Figure 2. Reconnaissance bedrock geologic map of the northwestern part of the Milford, N.H., 7.5-minute quadrangle. Base from U.S. Geological Survey, scale 1:24:000, 1985. Area of figure 1 shown (box). CHFZ = Campbell Hill fault zone. 


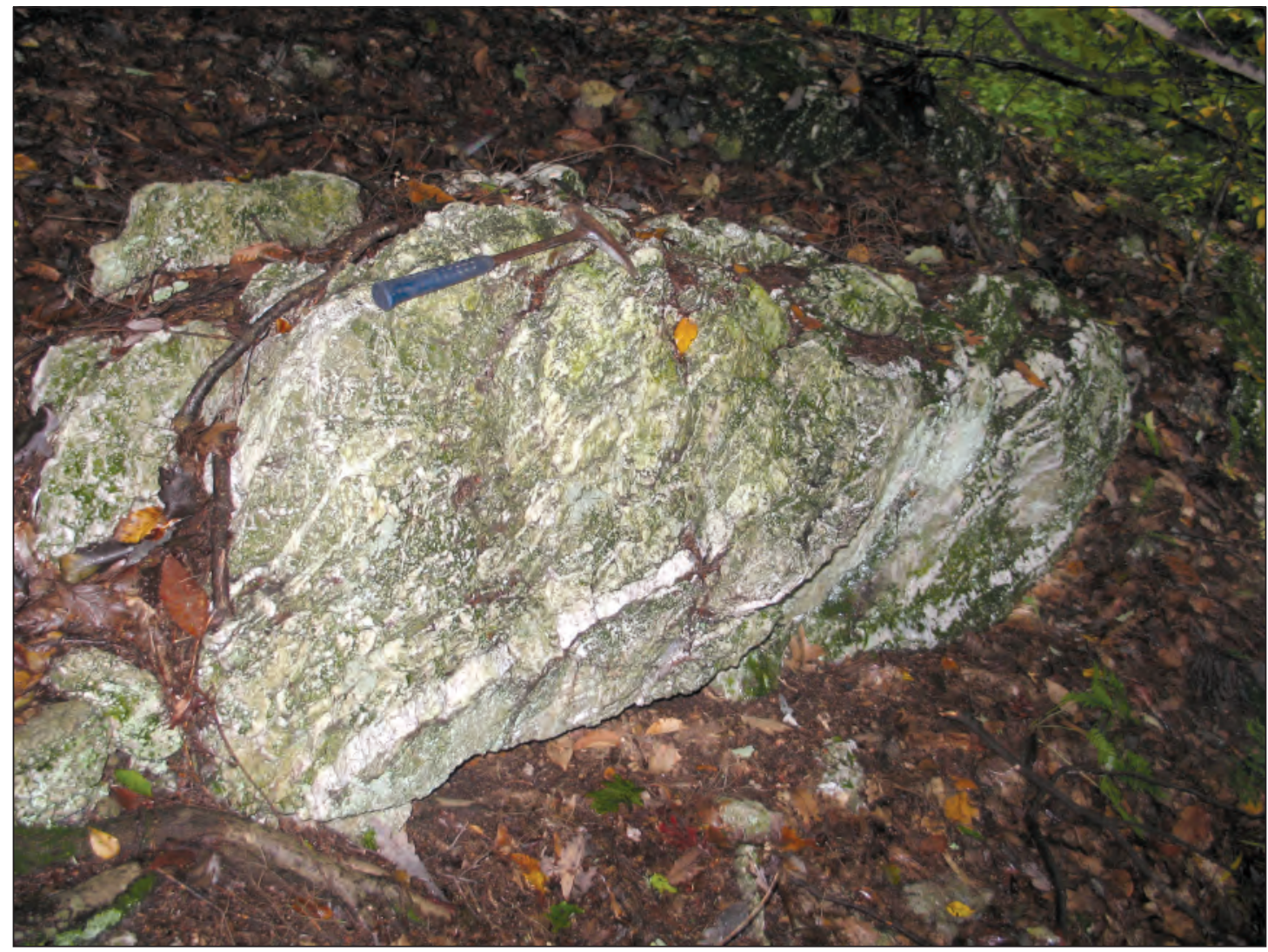

Figure 3. Body of vein quartz, q in figure 2, along the Campbell Hill fault zone south of the Souhegan River. Rock hammer shown for scale. 

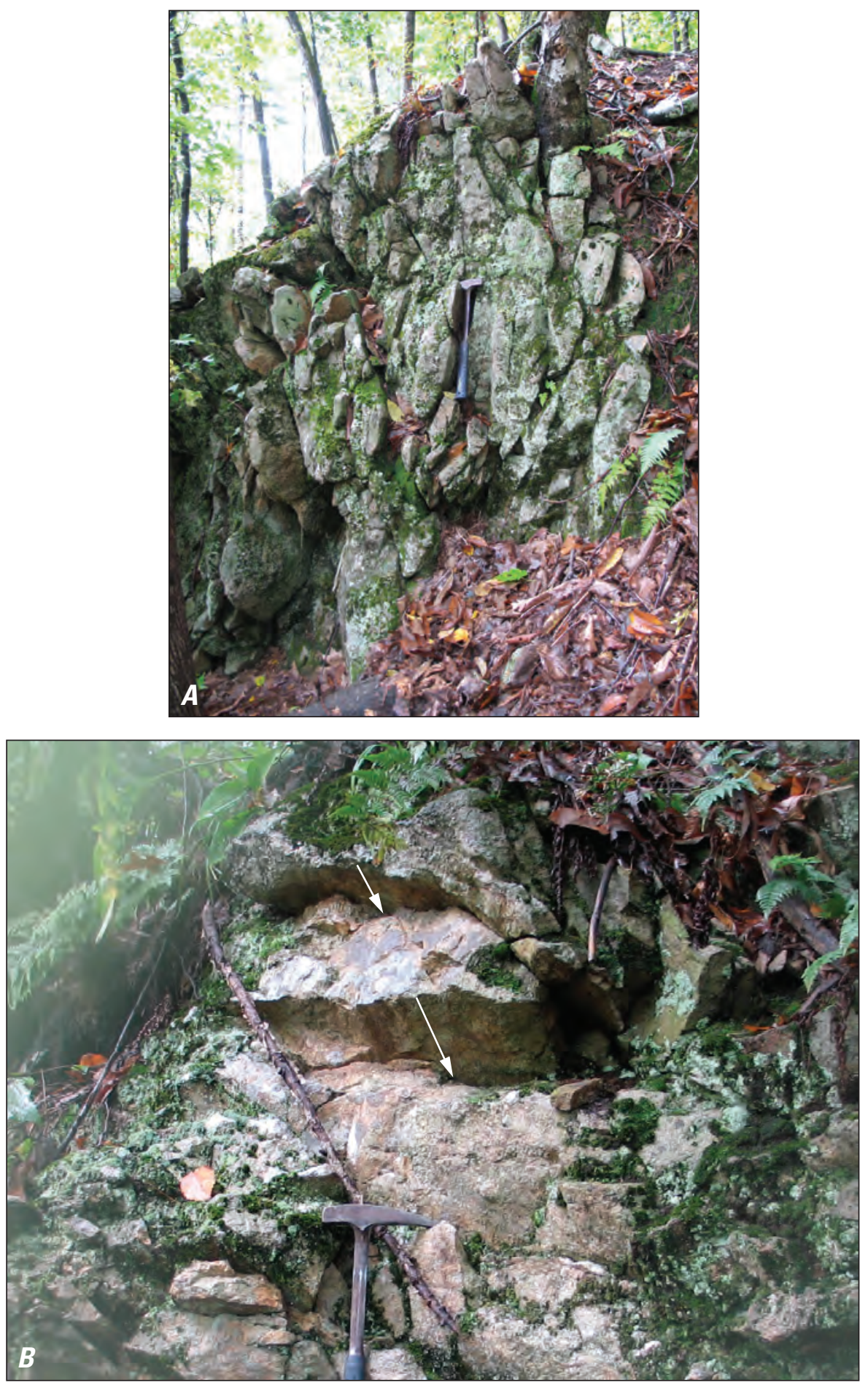

Figure 4. Brittle structures in an outcrop of Spaulding Tonalite along the Campbell Hill fault about 0.5 kilometer south of the body of vein quartz shown in figure 3. $(A)$ Subvertical fracture zone and $(B)$ west-dipping, slickensided minor faults; map symbols along Campbell Hill Fault Zone in figure 2. Arrows denote direction of slickenlines. Rock hammer shown for scale. 

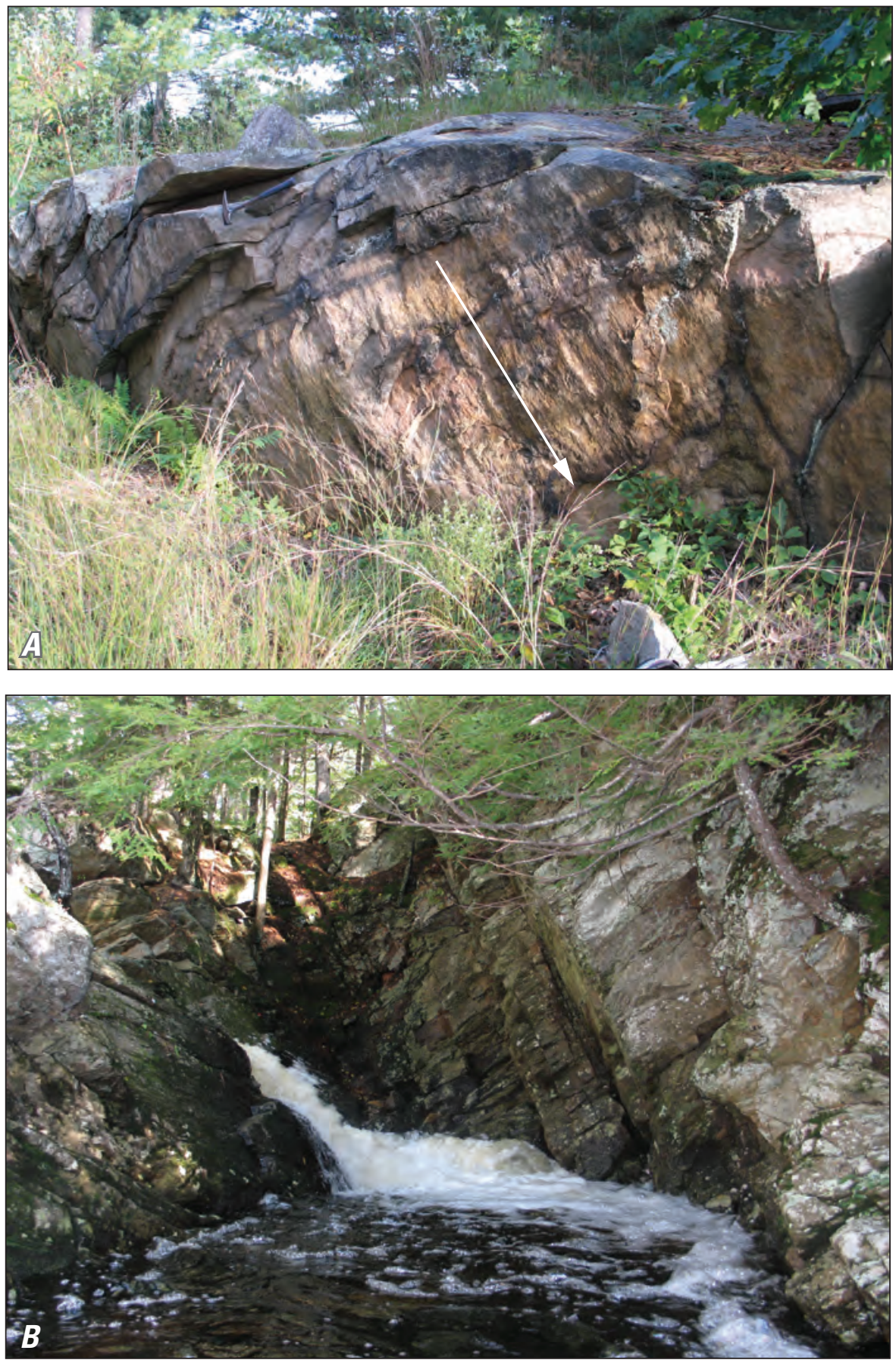

Figure 5. Brittle features north of the Souhegan River. $(A)$ Slickensided fault surface in Milford granite; map symbol along North River Road, figure 2. Arrow denotes direction of slickenlines; hammer is parallel to gently dipping exfoliation joints. $(B)$ North-northeasttrending, southeast-dipping joint set in Rangeley Formation schist at Purgatory Falls. 


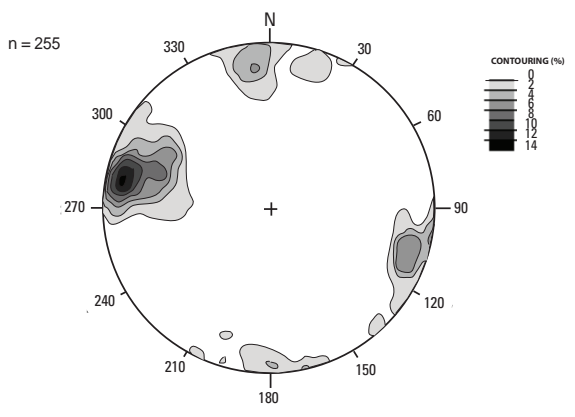

Milford all
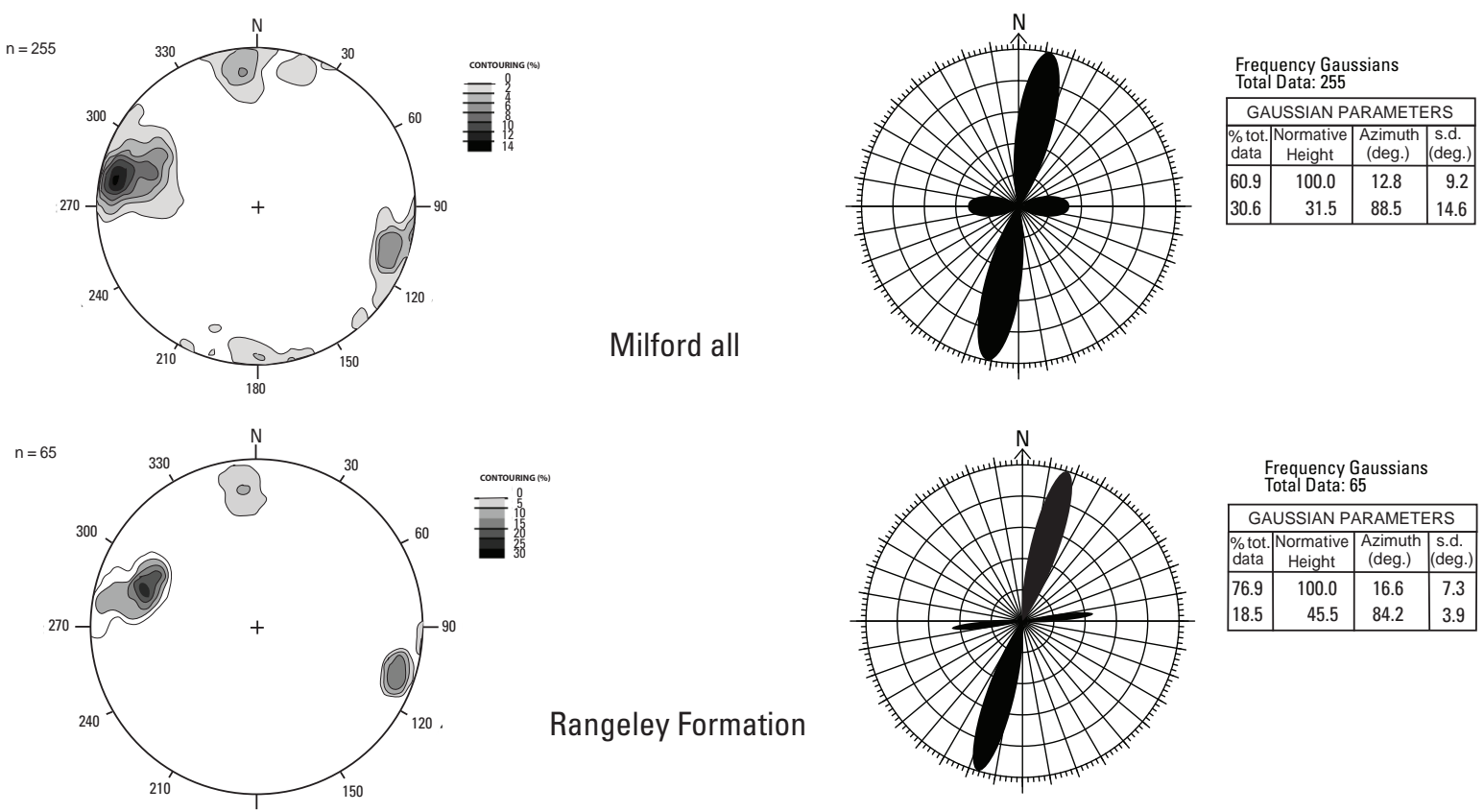

Rangeley Formation
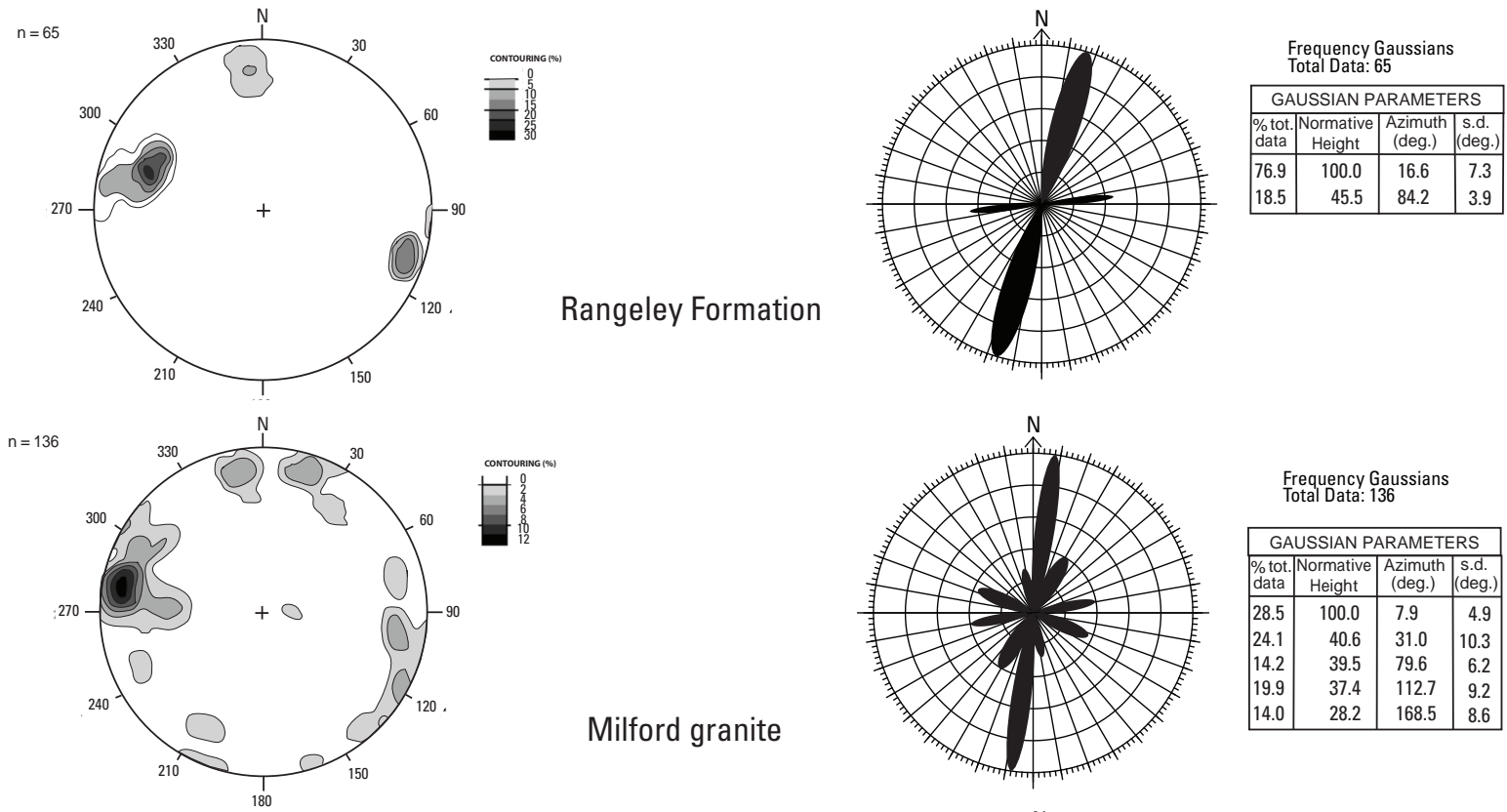

Milford granite
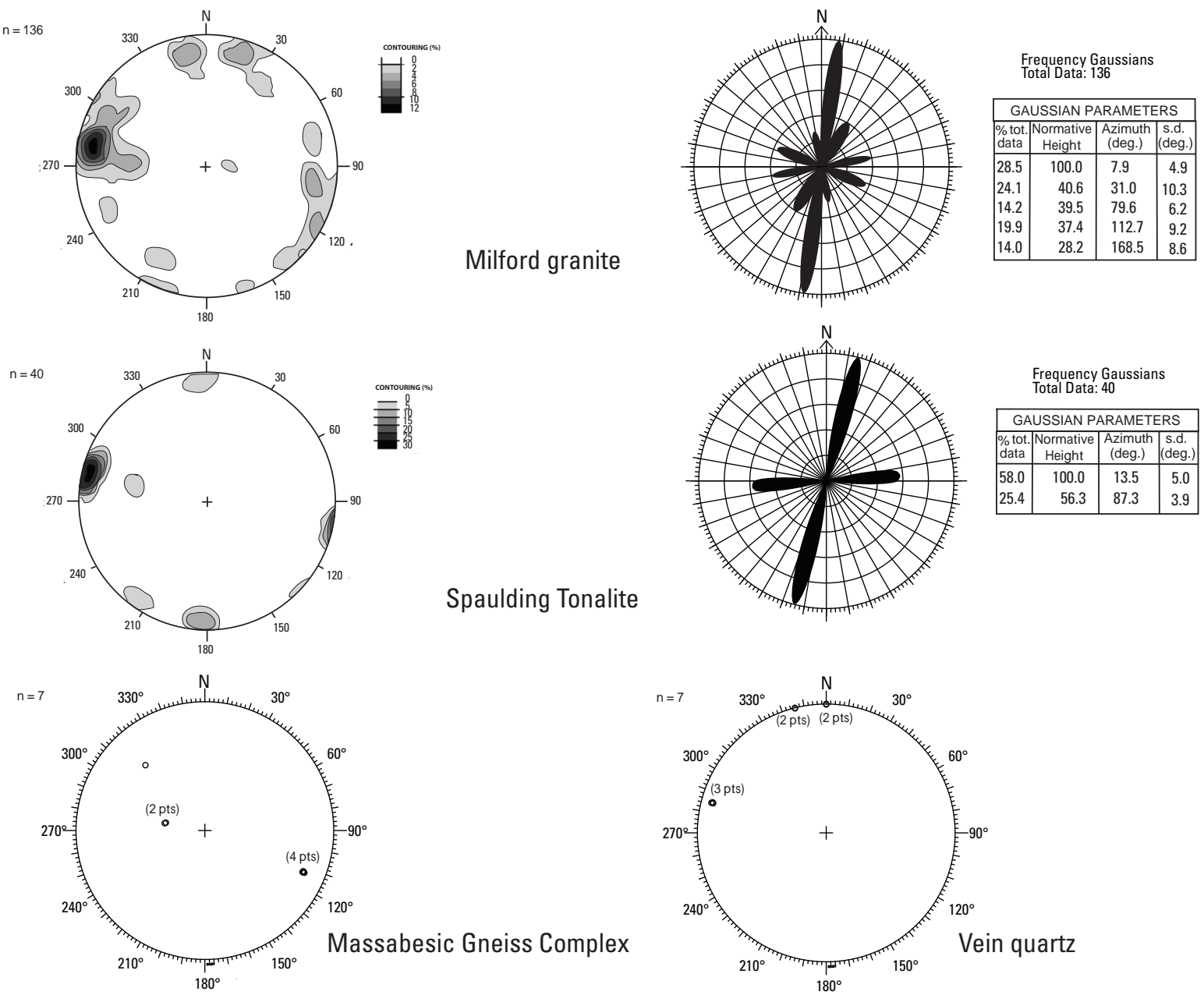

Figure 6. Measured joint orientations in natural outcrops and man-made roadcuts within 3 kilometers of Savage Municipal Well Superfund site. Left column: lower-hemisphere equal-area projections (stereonets) of contoured poles to planes; right column: azimuth-frequency (rose) diagrams of joints, accompanied by statistical data tables. Bottom row: lower-hemisphere equal-area projections of poles to planes for the Massabesic Gneiss Complex (left) and vein quartz (right). Data were plotted using Structural Data Integrated System Analyzer (DAISY) software, version 4.85 (Salvini, 2012). " $N$ " indicates north, and " $n$ " is the number of measurements. 
$\boldsymbol{A}$ 3-m spacing

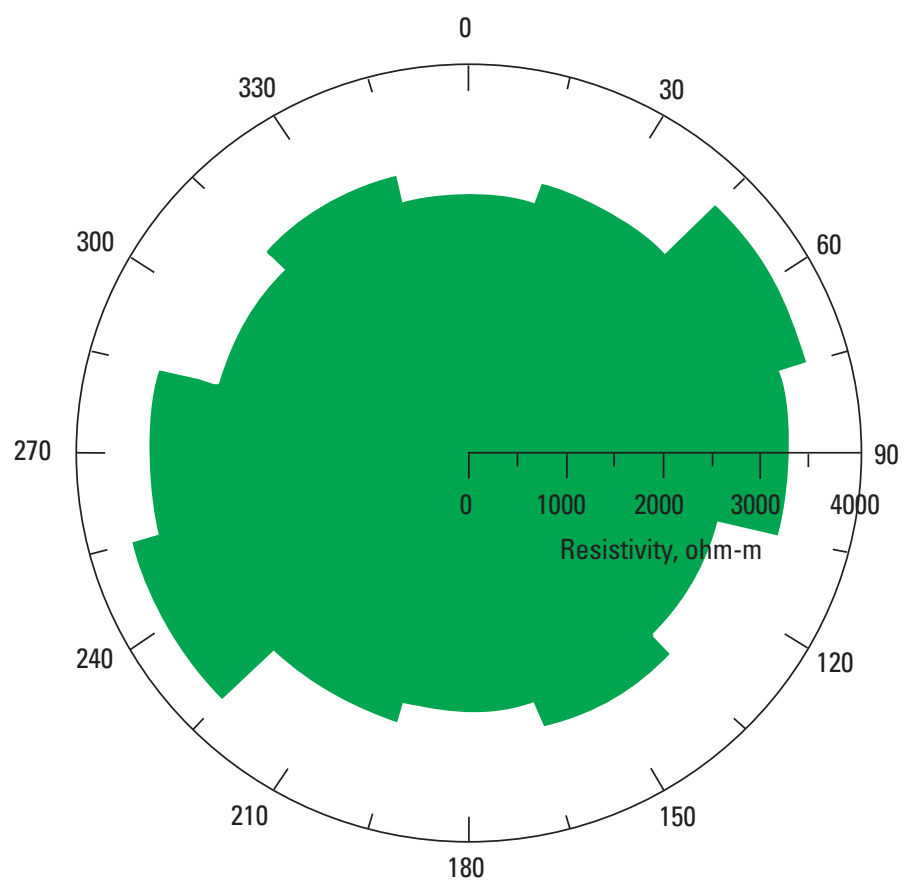

Angle, degrees

B

30-m spacing

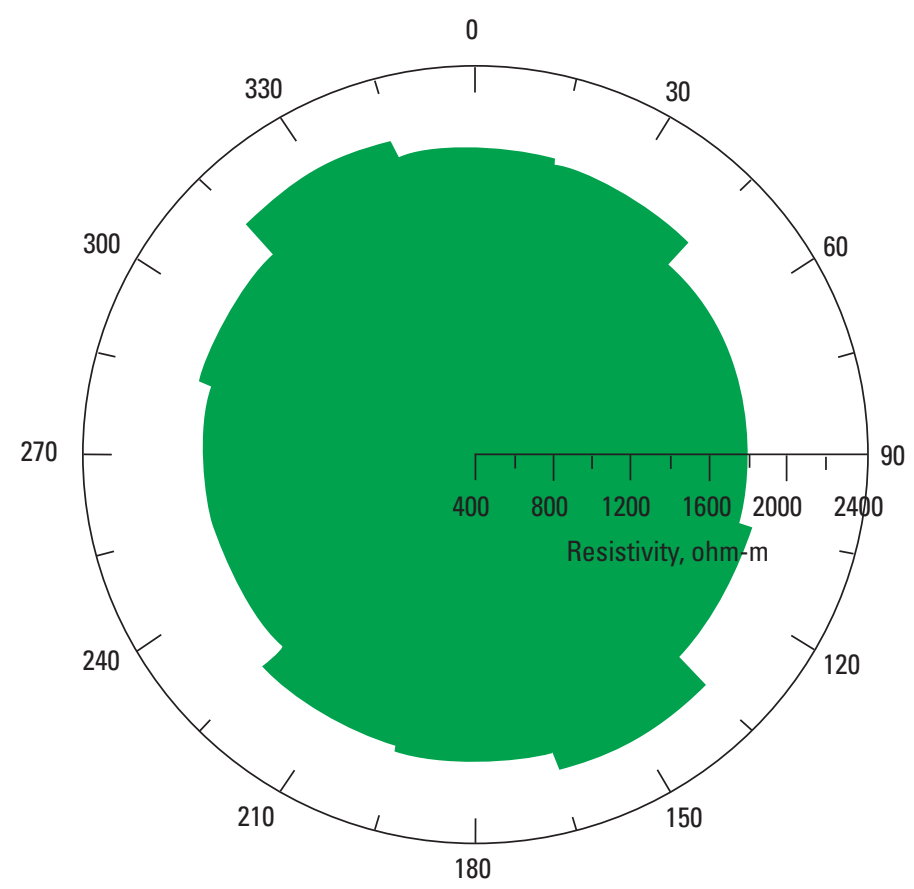

Angle, degrees

Figure 7. Polar plots showing results from azimuthal array directcurrent resistivity survey near North River Road. $(A)$ Resistivity measured at 3-m spacing and $(B)$ resistivity measured at 30-m spacing, in ohm-meters (ohm-m). 
$\boldsymbol{A}$

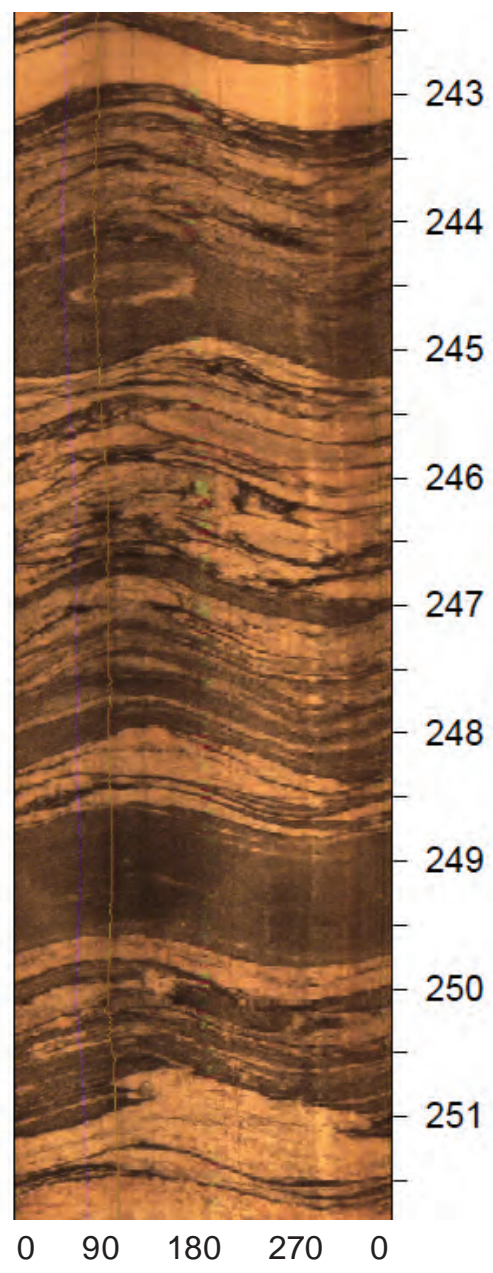

$\boldsymbol{B}$

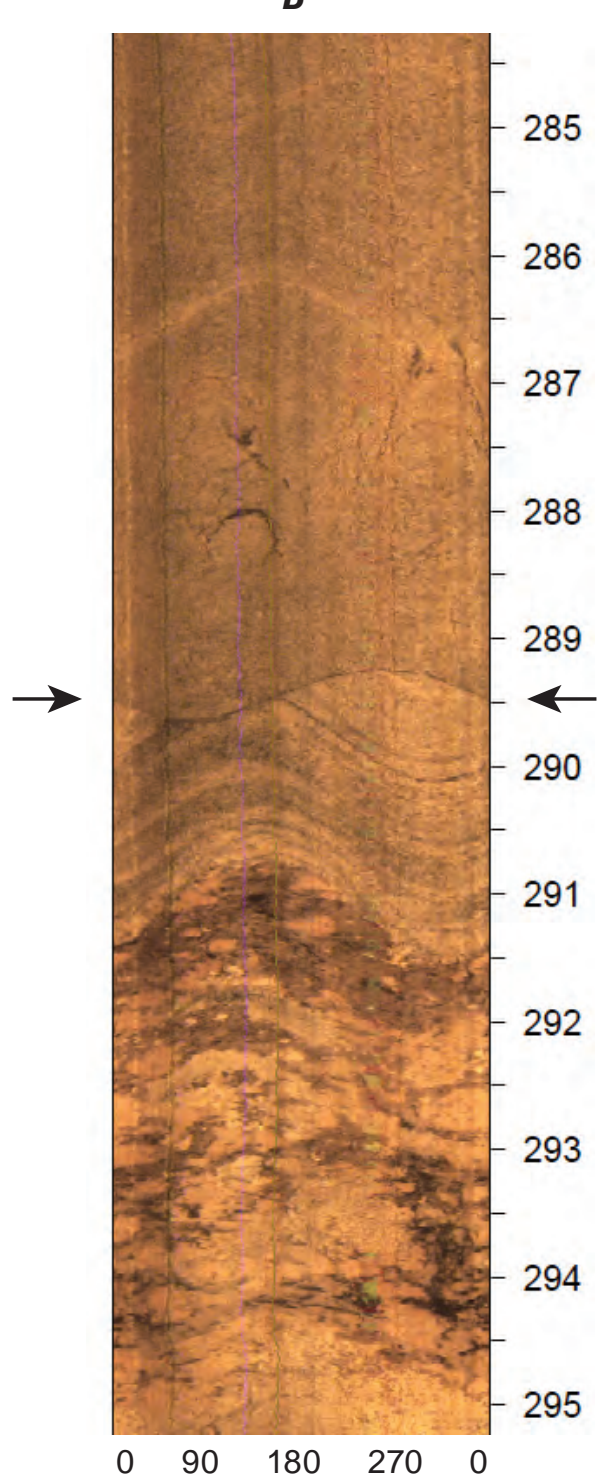

Figure 8. Features in optical televiewer logs of bedrock borehole BR-7. (A) Part of inclusion of Massabesic Gneiss Complex (PZmg) within Milford granite (Pmg), orientation of foliation shown in figure 2; and $(B)$ minor fault (indicated by arrows) offsetting foliation in Milford granite (Pmg) (from Weston, Inc., 2012). Vertical scale in feet (depth in borehole); horizontal scale in degrees of azimuth. 
$\boldsymbol{A}$

BR-5

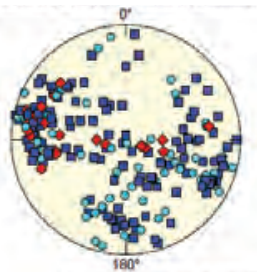

Counts Dip/degl Axideg]

\begin{tabular}{llll}
210 & $56.16 \quad 37.98$ \\
\hline
\end{tabular}

$\begin{array}{llll}\text { a } & 128 & 56.37 & 50.93 \\ - & 24 & 52.90 & 91.50 \\ -\quad 58 & 5703 & 351.72\end{array}$

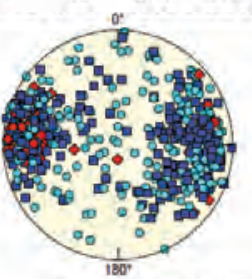

Counts Dipldegl Azi[deg]

Mean $\quad 524 \quad 6106 \quad 20260$

\begin{tabular}{llll}
$-\quad 40$ & 68.41 & 99.43 \\
$-\quad 223$ & $5959 \quad 24183$ \\
\hline
\end{tabular}

\begin{tabular}{lll} 
- $\quad 261 \quad 61.17$ & 202.85 \\
\hline
\end{tabular}
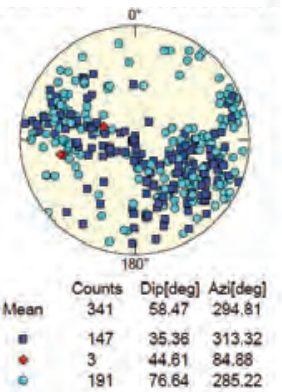
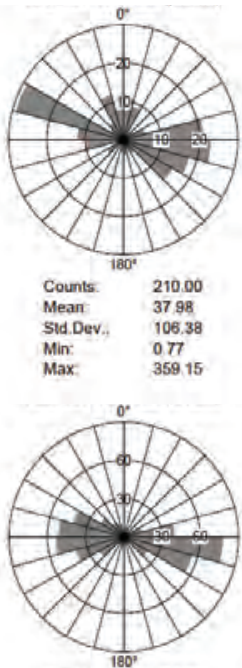

Counts: $\quad 524.00$ $\begin{array}{ll}\text { Mean: } & 202.60 \\ \text { Sta. Dev. } & 131.83\end{array}$

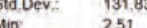

Max $\quad 35710$

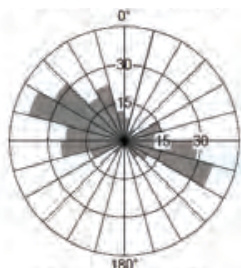

Counts: Mean: Min:
BR-8
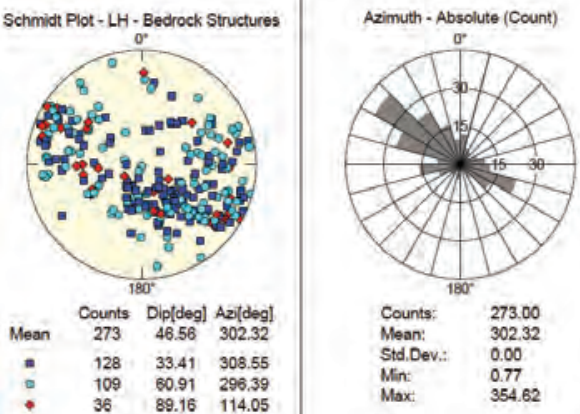

counts: $\begin{array}{ll}\text { Counts: } & 273.00 \\ \text { Mean: } & 302.32 \\ \text { Std Dey:- } & 0.00\end{array}$ Std.Dev:: $\quad 0.00$ Man:

354.62

MW-16R

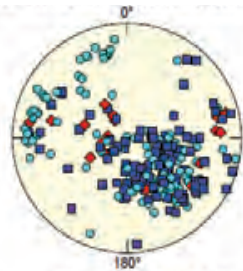

$\begin{array}{ccc}\text { Counts Dip[degl Azi|deg] } \\ 279 & 4542 \quad 31839\end{array}$

- $\quad 137 \quad 41.31 \quad 31520$

\begin{tabular}{lll}
121 & 4975 & 32553 \\
21 & 4729 & 121.75 \\
\hline
\end{tabular}

MW-30

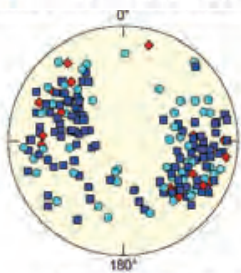

Counts Dipldeg] Azz[deg]

\begin{tabular}{llll}
0 & 107 & 86.32 & 104.07 \\
$-\quad$ & 21 & 86.94 & 117.06 \\
\hline
\end{tabular}

$\begin{array}{llll}21 & 86.94 & 117.06 \\ : \quad 59 & 60.22 & 290.40\end{array}$

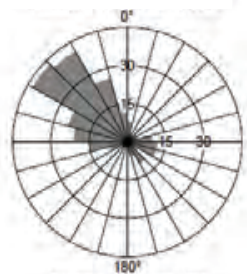

Counts: $\quad 279.00$ $\begin{array}{ll}\text { Mean: } & 318.3 \\ \text { Std Der. } & 73.11\end{array}$ $\operatorname{Min} \quad 0.37$

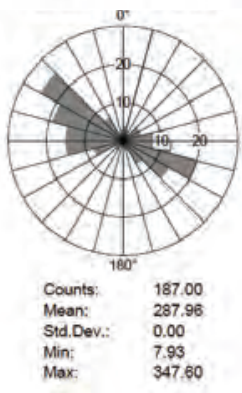

ID Fracture Rank 1 - Fracture Rank 2 Fracture Rank 3
B

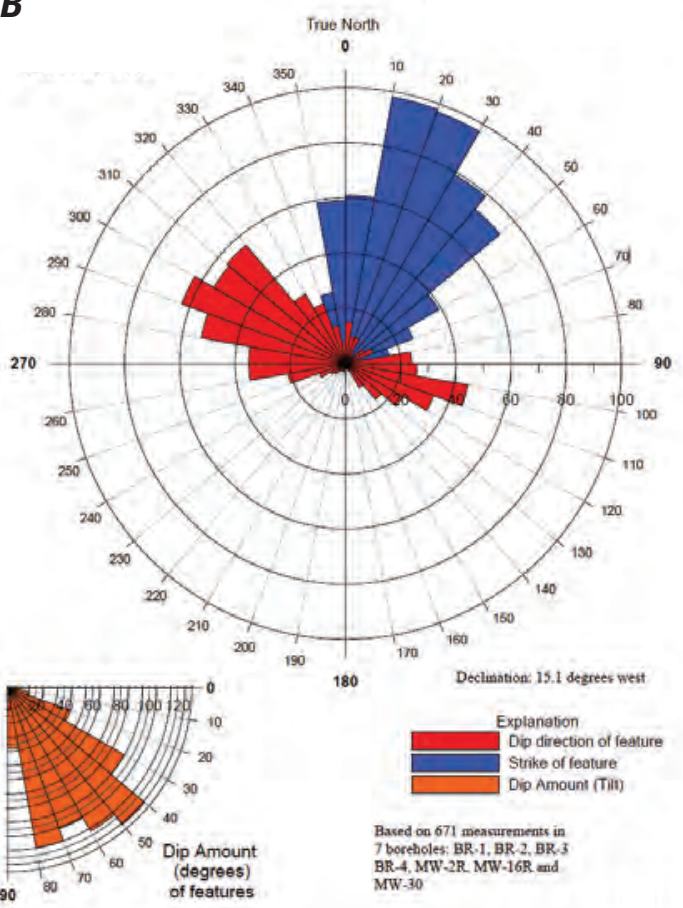

Figure 9. Summary orientation diagrams of planar features in bedrock boreholes (Weston, Inc., 2012). (A) Fractures in selected wells; geophysical logging by Hager-Richter Geoscience. Locations are shown in figure 1. Left column: stereonets of poles to fractures ranked by transmissive potential. Light-blue symbol indicates indistinct, typically discontinous fracture (Fracture Rank 1); dark-blue symbol indicates distinct, continuous fracture with no apparent aperture (Fracture Rank 2); red symbol indicates distinct, continuous fracture with apparent aperture (Fracture Rank 3). Right column: rose diagrams of dip azimuths for all fractures. (B) Rose diagram of strike (blue petals) and dip direction (red petals) for all planar features (including foliation) in seven boreholes; geophysical logging by Northeast Geophysical. Locations are shown in figure 1. 
For additional information regarding this publication, contact:

Eastern Geology and Paleoclimate Science Center U.S. Geological Survey

926A National Center

12201 Sunrise Valley Drive

Reston, VA 20192

or

William C. Burton

U.S. Geological Survey

926A National Center

12201 Sunrise Valley Drive

Reston, VA 20192

Email: bburton@usgs.gov

Publishing support provided by the Raleigh and Reston Publishing Service Centers. 


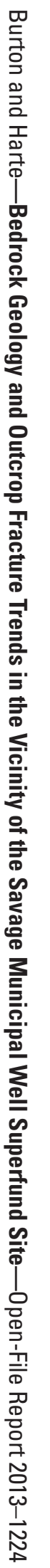

